\title{
Performed Substance Administration Dose
}

National Cancer Institute

\section{Source}

National Cancer Institute. Performed Substance Administration Dose. NCI Thesaurus.

Code C93971.

The quantity of a substance or medication used in a substance administration. 